\title{
Effects of Hidden Curriculum on Students' Learning in Undergraduate Medical Education in Bangladesh Students' Views
}

\author{
Brigadier General (Dr) Md Rahimgir', Brigadier General (Dr) Md Ahsan Habib', Professor (Dr) Md Humayun Kabir Talukder ${ }^{3}$
}

\begin{abstract}
The present study was conducted amongst fourth and fifth year MBBS students of six medical colleges ( 4 govt. \& 2 nongovt.) of Bangladesh to study their views regarding hidden curriculum and its effects on students learning in undergraduate medical education. A total of 637 students were included in the study. Out of 637 students, 393(61.7\%) were female and 244(38.3\%) male students. Three hundred and fifty (54.95\%) were from fourth year and 287(45.05\%) students were from fifth year MBBS. Most of the students (96.7\%) agreed that teachers' good behavior with students influences students' active participation in the class. The mean score was highly satisfactory(mean $4.68 \pm 0.643$ ). Of the total responded students, $58.9 \%$ strongly agreed that teachers' good behavior with parents influences students to do the same, and mean score was highly satisfactory. More than $87 \%$ agreed that teachers' good behavior with colleagues influence students to do so. The mean score was $4.40 \pm 0.730$ and it was also highly satisfactory. Around $70 \%$ of the students strongly agreed that teachers' good behavior with the patients and attendances influences students to maintain similar behavior and attitude with the patients and attendances. The mean score was $4.64 \pm 0.643$. As per views' of the students, teachers' depth of knowledge, devotion to the work, interest in the subject, honesty, fairness, teachers' language and art of expression also affects students learning. The mean score was more than four as opined by the students in favor of institutional educational environment, cultural norms, values, traditions all of which can affect students' learning. Teachers' humiliation of the students, gender discriminations, social class difference, and students' politics in the institutes all can affect students' learning badly. After data analysis it was observed that many of the hidden factors normally exists in the institutes that affect students' learning positively and others affect negatively.
\end{abstract}

Key Words: Hidden Curriculum, Students' Learning, Undergraduate Medical Education

\section{Introduction}

The hidden curriculum can be defined as the indelible messages, often nonverbal, that a person takes from an event or an experience. It is the essence, the soul that which is remembered after the source is forgotten. Hidden curriculum is the part of education that every member of an academic department will participate in and contribute to. We are each a part of an educational process all the times. How we exchange information with each other and the language we use, our intellectual honesty, and the respect we have for one another are important ${ }^{1}$. The medical school is best thought of as a learning environment and reform initiatives must be undertaken with an eye to what students learn instead of what they are taught. The concept of informal and hidden curriculum stands in contrast to that of formal curriculum ${ }^{2}$. There is fundamental distinction between what students are taught and what they learn in the institute ${ }^{3}$. The informal



Address of correspondence: Brigadier General (Dr) Md Rahimgir Professor \& Head, Department of Microbiology, Armed Forces Medical College, Dhaka Cantonment, Dhaka.

E-mail: rahimgir@yahoo.com curriculum targets learning at the level of interpersonal interactions. Hidden curriculum is in operation all the times and conveys unspoken messages to the students about values, norms, attitudes, principles and ethics ${ }^{2}$. Impact of hidden curriculum can be ascertained within any number of domains. Some scholars such as Smith and Montgomery in their research showed that students' attitudes to various courses are influenced by school governor valuation process in lessons ${ }^{4}$.

Hidden curriculum often refers to knowledge gained in primary and secondary school settings, usually with a negative connotation where the school strives for equal intellectual development ${ }^{5}$. Castellana $\mathrm{E}$ written that schools often restrict freedom with the promise that they are "preparing (students) for freedom later and elsewhere" 6 And what is the value of freedom in education and life? In real life setting the dual role of a teacher and clinician can be complicated. The students will be closely observing the clinician; picking up the hidden messages about clinical practice ${ }^{7}$.The hidden curriculum highlights the importance and impact of structural factors on the learning process. Hidden curriculum is the set of influences that function at the level of organizational structure and culture including, for example implicit rules to survive the institute such as customs, rituals and taken for granted aspects ${ }^{8}$. The aim of this study was to find out the effects of hidden curriculum in undergraduate medical education of Bangladesh by studying the views of students' in selected medical colleges.

Bangladesh Journal of Medical Education 2018;9(1):1-6. C 2018 Rahimgir et al., publisher and licensee Association for Medical Education. This is an Open Access article which permits unrestricted non-commercial use, provided the original work is properly cited. 


\section{Methods and Materials}

It was a cross sectional descriptive study. Study period was from July 2016 to June 2017(One year). The study places were four government and two non-government medical colleges of Bangladesh. Fourth \& 5th year MBBS students of the selected six medical colleges excluding foreigners were the study population. Sample size was 637 medical students. A self-administered semi-structured questionnaire was prepared for data collection. Questionnaires were distributed amongst the students and data were collected from the students at end of the lecture classes. Medical colleges were selected purposively and students were selected conveniently. After collection, data were checked and then entered into the software of the computer for analysis. SPSS program(IBM SPSS statistics 19) was used for data analysis. Likert scale was used to measure responses of the respondents of each item. Scores were given to each scale as: strongly agree $=5$, agree $=4$, neither agree nor disagree $=3$, disagree $=2$, strongly disagree $=1$. Interpretations of the mean scores were: If mean score was $>4$ : situation of the item areas were highly satisfactory. If mean score was $>3-4$ : situation of the item areas were satisfactory. If mean score was $>2-3$ : situation of the item areas were not satisfactory. If mean score was $>1-2$ : situation of the item areas were very poor.

\section{Results}

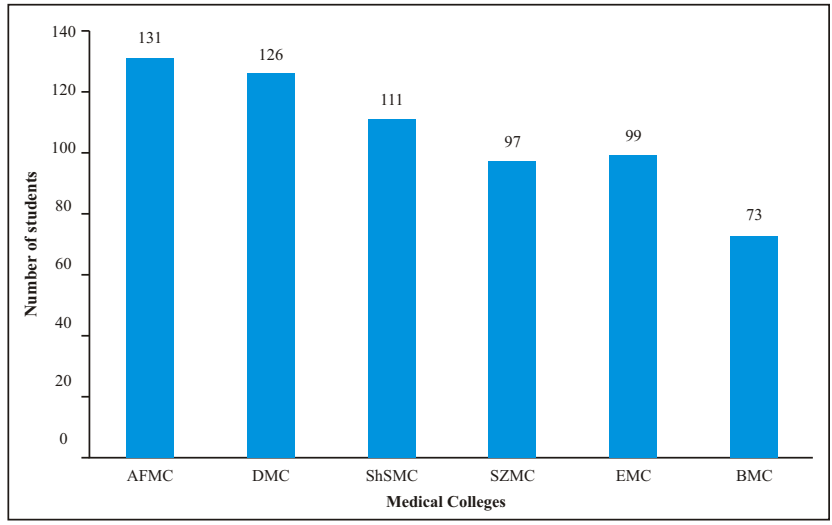

Figure 1: Frequency distribution of students from different medical colleges $(n=637)$

Figure 1 reveals 131(20.5\%) students were from Armed Forces Medical College(AFMC), 126(19.8\%) from Dhaka Medical College(DMC), 111(17.4\%) from Shahid Shohrawardi Medical College(ShSMC), 99(15.5\%) from Enam Medical College(EMC), 97(15.2\%) from Shahid Ziaur Rahman Medical College(SZMC) and 73(11.5\%) were from Bangladesh Medical College(BMC).

Table 1 Frequency distribution of students' views on teachers' behavior and attitude $(n=637)$

\begin{tabular}{|c|c|c|c|c|c|c|}
\hline & $\begin{array}{c}\text { SDA } \\
1\end{array}$ & $\begin{array}{c}\text { DA } \\
2\end{array}$ & $\begin{array}{l}\text { NAND } \\
3\end{array}$ & $\begin{array}{c}\text { A } \\
4\end{array}$ & $\begin{array}{c}\text { SA } \\
\mathbf{5}\end{array}$ & \multirow{2}{*}{$\begin{array}{l}\text { Mean } \\
\pm \text { SD }\end{array}$} \\
\hline & $\begin{array}{c}\mathbf{f} \\
(\%)\end{array}$ & $\begin{array}{c}\text { f } \\
(\%)\end{array}$ & $\begin{array}{c}\text { f } \\
(\%)\end{array}$ & $\begin{array}{c}\text { f } \\
(\%)\end{array}$ & $\begin{array}{c}\text { f } \\
(\%)\end{array}$ & \\
\hline Teachers' good behavior influences students active participation in the class & $\begin{array}{c}5.0 \\
(0.8)\end{array}$ & $\begin{array}{c}8.0 \\
(1.3)\end{array}$ & $\begin{array}{c}8.0 \\
(1.3)\end{array}$ & $\begin{array}{l}144.0 \\
(22.6)\end{array}$ & $\begin{array}{l}472.0 \\
(74.1)\end{array}$ & $\begin{array}{l}4.68 \pm \\
0.643\end{array}$ \\
\hline $\begin{array}{l}\text { Teachers' good behavior with patients } \& \text { attendances influence students to } \\
\text { do so }\end{array}$ & $\begin{array}{c}4.0 \\
(0.6)\end{array}$ & $\begin{array}{c}7.0 \\
(1.1\end{array}$ & $\begin{array}{l}13.0 \\
(2.0)\end{array}$ & $\begin{array}{l}166.0 \\
(26.1)\end{array}$ & $\begin{array}{l}447.0 \\
(70.2)\end{array}$ & $\begin{array}{l}4.64 \pm \\
0.643\end{array}$ \\
\hline $\begin{array}{l}\text { Teachers' good behavior with staffs influences students to maintain same } \\
\text { with the staff }\end{array}$ & $\begin{array}{l}5.0 \\
(0.8)\end{array}$ & $\begin{array}{c}8.0 \\
(1.3)\end{array}$ & $\begin{array}{l}36.0 \\
(5.7)\end{array}$ & $\begin{array}{l}235.0 \\
(36.9)\end{array}$ & $\begin{array}{l}353 . \\
(55.4)\end{array}$ & $\begin{array}{l}4.45 \pm \\
0.729\end{array}$ \\
\hline Teachers' good behavior with parents influence students to do so & $\begin{array}{c}4.0 \\
(0.6)\end{array}$ & $\begin{array}{l}12.0 \\
(1.9)\end{array}$ & $\begin{array}{l}39.0 \\
(6.1)\end{array}$ & $\begin{array}{l}207.0 \\
(32.5)\end{array}$ & $\begin{array}{l}375.0 \\
(58.9)\end{array}$ & $\begin{array}{c}4.47 \pm \\
0.749\end{array}$ \\
\hline Teachers' good behavior with colleagues influence students to do so & $\begin{array}{l}1.0 \\
(0.2)\end{array}$ & $\begin{array}{l}11.0 \\
(1.7) \\
\end{array}$ & $\begin{array}{l}54.0 \\
(8.5) \\
\end{array}$ & $\begin{array}{l}237.0 \\
(37.2) \\
\end{array}$ & $\begin{array}{l}334.0 \\
(52.4) \\
\end{array}$ & $\begin{array}{c}4.40 \pm \\
0.730\end{array}$ \\
\hline Teachers' honesty influences students to be honest & $\begin{array}{c}3.0 \\
(0.5)\end{array}$ & $\begin{array}{l}13.0 \\
(2.0)\end{array}$ & $\begin{array}{l}40.0 \\
(6.3)\end{array}$ & $\begin{array}{l}230.0 \\
(36.1)\end{array}$ & $\begin{array}{l}351.0 \\
(55.1)\end{array}$ & $\begin{array}{c}4.43 \pm \\
0.742\end{array}$ \\
\hline Teachers' fairness influences students to maintain fairness at all levels & $\begin{array}{c}7.0 \\
(1.1) \\
\end{array}$ & $\begin{array}{l}22.0 \\
(3.5) \\
\end{array}$ & $\begin{array}{l}54.0 \\
(8.5) \\
\end{array}$ & $\begin{array}{l}271.0 \\
(42.5) \\
\end{array}$ & $\begin{array}{l}283.0 \\
(44.4) \\
\end{array}$ & $\begin{array}{c}4.26 \pm \\
0.837 \\
\end{array}$ \\
\hline Teachers' gesture, posture $\&$ smartness influence students to be smart & $\begin{array}{c}5.0 \\
(0.8)\end{array}$ & $\begin{array}{l}24.0 \\
(3.8) \\
\end{array}$ & $\begin{array}{c}82.0 \\
(12.9)\end{array}$ & $\begin{array}{l}265.0 \\
(41.6)\end{array}$ & $\begin{array}{l}261.0 \\
(41.0)\end{array}$ & $\begin{array}{c}4.18 \pm \\
0.853\end{array}$ \\
\hline Teachers language $\&$ art of expression influence students learning & $\begin{array}{c}2.0 \\
(0.3)\end{array}$ & $\begin{array}{l}18.0 \\
(2.8)\end{array}$ & $\begin{array}{l}41.0 \\
(6.4)\end{array}$ & $\begin{array}{l}252.0 \\
(39.6)\end{array}$ & $\begin{array}{l}324.0 \\
(50.9)\end{array}$ & $\begin{array}{c}4.38 \pm \\
0.756\end{array}$ \\
\hline
\end{tabular}

Note: SDA-Strongly disagreed, DA-Disagreed, NAND-Neither agreed nor disagreed, A-Agreed, SA-Strongly agreed, SDStandard deviation 
Table 2: Frequency distribution of students' views on socio-cultural effects on students' learning $(n=637)$

\begin{tabular}{|c|c|c|c|c|c|c|}
\hline & $\begin{array}{c}\text { SDA } \\
1\end{array}$ & $\begin{array}{c}\text { DA } \\
2\end{array}$ & $\begin{array}{c}\text { NAND } \\
\mathbf{3}\end{array}$ & $\begin{array}{l}\mathbf{A} \\
\mathbf{4}\end{array}$ & $\begin{array}{c}\text { SA } \\
5\end{array}$ & \multirow{2}{*}{$\begin{array}{l}\text { Mean } \\
\pm \text { SD }\end{array}$} \\
\hline & $\begin{array}{c}\mathbf{f} \\
(\%)\end{array}$ & $\begin{array}{c}\text { f } \\
(\%)\end{array}$ & $\begin{array}{c}\text { f } \\
(\%)\end{array}$ & $\begin{array}{c}\text { f } \\
(\%)\end{array}$ & $\begin{array}{c}\mathbf{f} \\
(\%)\end{array}$ & \\
\hline $\begin{array}{l}\text { Cultural norms and values have good effect on students' } \\
\text { behavior \& attitude }\end{array}$ & $\begin{array}{c}6.0 \\
(0.9)\end{array}$ & $\begin{array}{l}26.0 \\
(4.1)\end{array}$ & $\begin{array}{l}63.0 \\
(9.9)\end{array}$ & $\begin{array}{l}325.0 \\
(51.0)\end{array}$ & $\begin{array}{l}217.0 \\
(34.1)\end{array}$ & $\begin{array}{c}24.13 \pm \\
\mathbf{0 . 8 1 9}\end{array}$ \\
\hline $\begin{array}{l}\text { Institutional cultural traditions have good effect on students' } \\
\text { learning }\end{array}$ & $\begin{array}{c}6.0 \\
(0.9)\end{array}$ & $\begin{array}{l}11.0 \\
(1.7)\end{array}$ & $\begin{array}{l}47.0 \\
(7.4)\end{array}$ & $\begin{array}{l}310.0 \\
(48.7)\end{array}$ & $\begin{array}{l}263.0 \\
(41.3)\end{array}$ & $\begin{array}{c}4.28 \pm \\
\mathbf{0 . 7 5 2}\end{array}$ \\
\hline $\begin{array}{l}\text { Institutional cultural rituals have good effect on students } \\
\text { learning }\end{array}$ & $\begin{array}{l}10.0 \\
(1.6)\end{array}$ & $\begin{array}{l}24.0 \\
(3.8)\end{array}$ & $\begin{array}{c}74.0 \\
(11.6)\end{array}$ & $\begin{array}{l}300.0 \\
(47.1)\end{array}$ & $\begin{array}{l}229.0 \\
(35.9)\end{array}$ & $\begin{array}{c}4.12 \pm \\
0.868\end{array}$ \\
\hline Social class difference affects students' learning badly & $\begin{array}{c}69.0 \\
(10.8)\end{array}$ & $\begin{array}{l}177.0 \\
(27.8)\end{array}$ & $\begin{array}{l}151.0 \\
(23.7)\end{array}$ & $\begin{array}{l}154.0 \\
(24.2)\end{array}$ & $\begin{array}{c}86.0 \\
(13.5)\end{array}$ & $\begin{array}{l}3.02 \pm \\
1.223\end{array}$ \\
\hline $\begin{array}{l}\text { Teachers different attitude towards different gender affects } \\
\text { students learning badly }\end{array}$ & $\begin{array}{l}44.0 \\
(6.9)\end{array}$ & $\begin{array}{c}81.0 \\
(12.7)\end{array}$ & $\begin{array}{l}81.0 \\
(12.7)\end{array}$ & $\begin{array}{l}215.0 \\
(33.8)\end{array}$ & $\begin{array}{l}216.0 \\
(33.9)\end{array}$ & $\begin{array}{l}3.75 \pm \\
1.240\end{array}$ \\
\hline
\end{tabular}

Table 1 reveals that teachers' good behavior with students, staffs, patients, attendances, parents and colleagues influences students' learning positively(mean $>4)$. Teachers honesty, fairness, gesture, posture, smartness, language and art of expression also influence students' learning (mean $>4)$.

Table 2 describes that socio-cultural norms, values, traditions and rituals have good effects on students' learning(mean $>4)$. But social class difference and gender discrimination have bad effect on students' learning the study reveals $($ mean $>3-4)$.

Table 3: Frequency distribution of students' views on institutional educational environment on students' learning $(\mathrm{n}=637)$

\begin{tabular}{|c|c|c|c|c|c|c|}
\hline & $\begin{array}{c}\text { SDA } \\
1\end{array}$ & $\begin{array}{c}\text { DA } \\
2\end{array}$ & $\begin{array}{c}\text { NAND } \\
3\end{array}$ & $\begin{array}{l}\mathrm{A} \\
4\end{array}$ & $\begin{array}{c}\text { SA } \\
5\end{array}$ & \multirow{2}{*}{$\begin{array}{l}\text { Mean } \\
\pm \text { SD }\end{array}$} \\
\hline & $\begin{array}{c}\text { f } \\
(\%)\end{array}$ & $\begin{array}{c}f \\
(\%)\end{array}$ & $\begin{array}{c}f \\
(\%)\end{array}$ & $\begin{array}{c}f \\
(\%)\end{array}$ & $\begin{array}{c}f \\
(\%)\end{array}$ & \\
\hline Educational environment in the institute affects students learning & $\begin{array}{c}9.0 \\
(1.4)\end{array}$ & $\begin{array}{l}20.0 \\
(3.1)\end{array}$ & $\begin{array}{l}47.0 \\
(7.4)\end{array}$ & $\begin{array}{l}301.0 \\
(47.3)\end{array}$ & $\begin{array}{l}260.0 \\
(40.8)\end{array}$ & $\begin{array}{c}4.23 \pm \\
\mathbf{0 . 8 2 7}\end{array}$ \\
\hline Cordial and friendly environment encourages students' learning & $\begin{array}{c}7.0 \\
(1.1)\end{array}$ & $\begin{array}{l}17.0 \\
(2.7)\end{array}$ & $\begin{array}{l}30.0 \\
(4.7)\end{array}$ & $\begin{array}{l}299.0 \\
(46.9)\end{array}$ & $\begin{array}{l}284.0 \\
(44.6)\end{array}$ & $\begin{array}{l}4.31 \pm \\
\mathbf{0 . 7 7 6}\end{array}$ \\
\hline $\begin{array}{l}\text { Teachers' timeliness in the class make students to become } \\
\text { punctual }\end{array}$ & $\begin{array}{l}12.0 \\
(1.9)\end{array}$ & $\begin{array}{l}32.0 \\
(5.0)\end{array}$ & $\begin{array}{c}67.0 \\
(10.5)\end{array}$ & $\begin{array}{l}308.0 \\
(48.4)\end{array}$ & $\begin{array}{l}218.0 \\
(34.2)\end{array}$ & $\begin{array}{l}4.08 \pm \\
\mathbf{0 . 9 0 2}\end{array}$ \\
\hline Teachers' humiliation affect students' learning negatively & $\begin{array}{l}15.0 \\
(2.4)\end{array}$ & $\begin{array}{l}40.0 \\
(6.3)\end{array}$ & $\begin{array}{c}71.0 \\
(11.1)\end{array}$ & $\begin{array}{l}193.0 \\
(30.3)\end{array}$ & $\begin{array}{l}318.0 \\
(49.9)\end{array}$ & $\begin{array}{l}4.19 \pm \\
\mathbf{1 . 0 1 9}\end{array}$ \\
\hline Students' politics affect students' learning negatively & $\begin{array}{l}54 . \\
(8.5)\end{array}$ & $\begin{array}{c}79.0 \\
(12.4)\end{array}$ & $\begin{array}{l}116.0 \\
(18.2)\end{array}$ & $\begin{array}{l}146.0 \\
(22.9)\end{array}$ & $\begin{array}{l}242.0 \\
(38.0)\end{array}$ & $\begin{array}{l}3.70 \pm \\
1.316\end{array}$ \\
\hline
\end{tabular}

Table 3 reveals that institutional educational environment affects students' learning(mean $>4)$. Cordial and friendly environment encourages students' learning. Teachers' humiliation affects students' learning badly(mean $>4)$. Students' politics also affect students' learning negatively(mean $>3-4)$.

\section{Discussion}

The hidden curriculum consists of experiences and learning that are not contained in the formal pronouncements of school syllabi. These pronouncements include goals, objectives, programs of studies, instructional methods, materials, assessment procedures, and so forth. Many curriculum analysts have focused on a discrepancy between what a curriculum says ought to be taking place in schools and what first hand observation reveals actually does not take place. This discrepancy underlies the concept of the hidden curriculum ${ }^{9}$. The hidden curriculum, what was once referred to by John Dewey as 'collateral learning', consists of all learning that takes place in the schools as a result of actions by the school personnel and students ${ }^{10}$. In this study it was found that most of the students $(96.7 \%)$ agreed that teachers' good behavior influences students' active participation in the class. Only around $2 \%$ of the students disagreed with the statement. The mean score was $4.68 \pm 0.643$.

Bangladesh Journal of Medical Education 2018;9(1):1-6. 
It indicates that students' views on teachers' behavior was very high. McConnell related high inference measures of teacher behavior to student attitude and achievement in 43 ninth-grade algebra classes. Positive attitudes were associated with teacher clarity, enthusiasm, and task orientation ${ }^{11}$. Flanders noted that teacher behavior variables may have "inverted U" curvilinear relationships or other nonlinear relationships with student achievement, so what is optimal teacher behavior may vary with the situation ${ }^{12}$. Nargis $\mathrm{T}$ observed in her study that the mean score of students' opinion was $3.14 \pm 1.24$ in relation to the statement, 'Teachers/Doctors always behaved well with the patients', and the opinion was satisfactory. In the same study she found doctors' behavior with patient's attendants' was not satisfactory, the mean score was $2.82 \pm 1.23$. In the same study her findings regarding staffs behavior with patients/attendances all the times was also not satisfactory \& the mean score was $2.29 \pm 1.07^{13}$. The present study revealed that more than $85 \%$ responded students agreed that cultural norms and values have good effect on students' behavior and attitude. The mean score of this statement was $>4$, which was highly satisfactory. A study was carried out by Kathryn HA, the author reviewed that social constructivism offers implications for reshaping schooling in ways that may correct the gap between the literacy achievement of students of diverse backgrounds and that of mainstream students ${ }^{14}$. Hidden curriculum has a strong cultural component, identified by Lamiani $\mathrm{G}$ et $\mathrm{a}^{15}$. In the present study more than $87 \%$ students agreed that institutional educational environment affects students learning. The mean score for this statement was highly satisfactory(mean $4.23 \pm 0.827$ ). The cordial and friendly environment in the institute encourages students' learning' was agreed by more than $90 \%$ of the students. The mean score of this statement was also highly satisfactory(mean $4.31 \pm 0.776$ ). Nargis T revealed in her study that more than $90 \%$ of the students perceived that there were differences in educational environment of the different departments and the mean score was unsatisfactory ${ }^{13}$. Chandratilake found in a study that most of the students perceived that the atmosphere during ward teaching was relaxing ${ }^{16}$. Jackson $\mathrm{P}$ identified features of classroom life that were inherent in the social relations of schooling. The author observed that there were values, dispositions, social and behavioral expectations that brought rewards in school for students and that learning what was expected along these lines was a feature of the hidden curriculum ${ }^{17}$.

\section{Conclusion}

Hidden curriculum is a side effect of an education. It includes lessons which are learned but not openly intended; such as the transmission of norms, values, and beliefs conveyed in the classroom and the social environment. Hidden curriculum is indirectly communicated to students through classroom rules, procedures, relationships, and structures. Medical education must adopt a new and more activist role within the culture of medicine. However, it can be better disseminated to the students by understanding how society outside of the school and classroom operates. The results of the present study findings can be used to make the authorities, teachers, other staffs, even students aware of the existence and the effects (both good and bad) of hidden curriculum on students learning in the institutes.

\section{References}

1. Anderson DJ. The hidden curriculum. American Journal of Roentgenology 1992; 159(1):21-22

2. Hafferty FW. Beyond curriculum reform: confronting medicine's hidden curriculum. Acad Med 1998; 73(4):403-407

3. Hafferty FW, Franks R. The hidden curriculum, ethics teaching, and the structure of Medical Education. Acad Med 1994; 69(11):861-870

4. Smith A, Montgomery A. Values and Hidden curriculum 2008. Available at http:// Cain web service. Browsed on 22 April 2017

5. Catherine C. Beyond Hidden Curriculum. Journal of Curriculum Studies 1984; 16(1): 2936

6. Castellana E. Prophylactic peace education: How the hidden curriculum in public schools prevents rather than promote building capacities for peace. 2004, Available at http://gseweb.harvard.edu. Browsed on 22 April 2017

7. Hutchinson L. Educational environment, $\mathrm{ABC}$ of teaching and learning in medicine. BMJ 2003; 326:810812

8. Lempp H, Seale C. The hidden curriculum in undergraduate medical education: A qualitative study of medical students' perception of teaching. BMJ 2004;329(2): 770-773

9. Massialas, B.G. The "New Social Studies" Retrospect and prospect. The Social Studies 2009;100(6): 246-250

10. Dewey J. Collateral learning: A reading from John Dewey with Discussion Questions. Experience and Education 2011; 1938:47-51

11. McConnell JW. Relationships between selected teacher behaviors and attitudes and achievements of algebra classes. Paper presented at the annual meeting of the American Educational Research Association, New York. 1977(ERIC Document No. ED141118):45

12. Flanders NA. Analyzing teacher behavior. Educational Leadership. Addision-Wesley 1970:173-200

13. Nargis T. The hidden curriculum in undergraduate medical education in Bangladesh: Medical students' perceptions. Thesis 2007:31-56

14. Kathryn HA. Social constructivism and school literacy learning of students of diverse backgrounds. Journal of literacy research 1998;30(2):297-319

15. Lamiani G, Leone D, Meyer EC, Moja EA. How Italian

Bangladesh Journal of Medical Education 2018;9(1):1-6. 
students learn to become physicians: a qualitative study of the hidden curriculum. Medical Teacher 2011;33(12):989-96

16. Chandratilake MN, Silva NR. Identifying poor concordance between the planned and the hidden curriculum at the time of curriculum change in a Sri
Lanka medical school using the Dundee ready education environment measure. South East Asian Journal of Medical Education 2009;3(2): 15-19

17. Jackson PW. Life in classrooms. 1968, NY: Holt, Rine hart and Wilson:1-177 